\title{
He kaiwhakatere ahau: $A(k)$ new practice model in the care of rangatahi and whānau
}

\author{
Georgina Denise Makoare, Ngāti Kahungunu \\ Zack Henare Makoare, Ngāti Kahungunu, Ngāti Porou, Rongomaiwahine, Ngāti Whatua \\ Fiona Cram, Ngāti Pāhauwera
}

\begin{abstract}
INTRODUCTION: A Kaiwhakatere position funded as part of Te Taitimu Trust's Ngā Moko A $\mathrm{Ngā}$ Tūpuna initiative has created a space for a navigation practice model within the context of suicide prevention. The Kaiwhakatere is akin to a "professional auntie" who draws on her knowledge of whakapapa, whenua and whānau to engage rangatahi and whānau and build their connectedness and confidence as Māori.
\end{abstract}

METHOD: Discussions with the Kaiwhakatere (Georgina) and the Chief Executive (Zack) of the Trust have explored the emergence of the Kaiwhakatere practice model. This model draws on Georgina's social work expertise and her recollections of her own upbringing.

IMPLICATIONS: The resulting Taikoko (rising spring tide) practice model of the Kaiwhakatere is grounded in Tākitimutanga to ensure that rangatahi and their whānau are connected to their cultural heritage, to their environment, and to a network of supports and relationships that facilitate their collective resiliency. Early feedback from rangatahi, whānau and education providers has been positive and encouraging.

KEYWORDS: Māori youth; suicide prevention; navigation; outdoor activities
Zack and Georgina Makoare founded Te Taitimu Trust (the Trust) in 2007 after the loss of their son Kelly to suicide in 2000. The Trust operates out of Flaxmere in Hawke's Bay and provides early intervention services throughout the Hawke's Bay and across Aotearoa New Zealand to prevent the loss of rangatahi lives to suicide. The success of the Trust's service delivery model has been documented in Professor Sir Mason Durie's (2018) writing, reports from Te Rau Matatini (Waka Hourua, 2017), Te Puni Kōkiri (2018, 2019), Water Safety New Zealand (2018), the New Zealand Police (2019), and has been described in various media reports.

This article describes the Trust's developing Kaiwhakatere navigator practice model.
The use of '(k)new' in the title of this article signals that this practice model is new in a contemporary professional sense, but knew in the sense that it is informed by traditional Māori practices. We begin with a brief overview of Te Taitimu Trust and its work. This provides a context for its Ngā Moko Ā Ngā Tūpuna initiative, of which the Kaiwhakatere is a part. The role of navigators within Indigenous contexts is then showcased as a lead-in to a description of the emerging Taikoko or rising spring tide practice model of the Kaiwhakatere.

\section{Te Taitimu Trust}

The original intention of the Trust was suicide prevention and, since its
AOTEAROA

NEW ZEALAND SOCIAL WORK 33(1), 5-16.

CORRESPONDENCE TO:

Fiona Cram

fionac@katoa.net.nz 
establishment, the foundations of this kaupapa have broadened to encompass the development of life skills and providing tamariki and rangatahi with outdoor, water-based experiences that they might not otherwise have access to.

Our tīpuna used the moana for rongoā, kai, wānanga and navigation where kaupapa, karakia and kawa associated with the moana was inherent; indigenous ways of knowing, being and doing.

(Te Taitimu Trust, 2018)

The recipients of the Trust's work are tamariki and rangatahi who are often described as vulnerable and at risk, including being at risk of suicide. Moving them to the outdoors through a connection to the water and water safety allows the Trust to connect safety in and on the water back to keeping themselves and their friends safe. Connecting tamariki and rangatahi to Tangaroa is seen as an integral part of healing for their hearts and minds. The Trust also works to grow these young people into the leaders of tomorrow (Water Safety New Zealand, 2018).

In May 2010, the Trust held a wānanga to refresh its vision and moved from Tai Mātātū (turning the tide) to Taikoko.

To open, Matua Mason [Durie] reminded us of four of the different tidal currents/stages: Taitimu (low tide), Taimātātū (the turn of the tide), Taikoko (spring tides) and Taipari (full tide). He referred to these as metaphor for sequential levels of wellness and used them to guide our wānanga: planning for the future towards finding Taipari (full tide). (Macfarlane, 2019, p. 2)
From the wānanga, the six spring tides of Taikoko were adopted by the Trust as the six pillars of wellbeing that are about being grounded in Tākitimutanga (i.e., the tribal traditions of those whose ancesters arrived in Aotearoa on the Tākitimu migration canoe) and the enduring heritage passed down from tīpuna, being connected to the environment, to whānau and to one another for collective resiliency, and being a catalyst for agencies and organisations to work together (see Figure 1). These are explored more below in the description of the Kaiwhakatere practice model.

\section{Ngā Moko ĀNgā Tūpuna}

Ngā Moko Ā Ngā Tūpuna is a model of early intervention developed by the Trust to combat risky environments that are pathways to suicide for rangatahi Māori. The objectives for Ngā Moko Ā Ngā Tūpuna are to:

1. Facilitate opportunities for tamariki/ rangatahi to participate in the social, economic, environmental, cultural and spiritual development of their lives, whānau and community.

2. Nurture whakawhanaungatanga (relationship building) throughout all aspects and activities, including the lives of tamariki/rangatahi.

3. Heal the hearts and minds of rangatahi through reconnecting them to Tangaroa.

4. Lower the rate of suicide and suicide attempts through talking openly with all members of our immediate

Overview of the Six Pillars of Wellbeing Within Taikoko

Taikoko - rising spring tide

\begin{tabular}{|l|l|l|l|l|l}
\multicolumn{1}{c|}{ Tākitimutanga } & \multicolumn{1}{c|}{ Taiope } & Taiohi & Taipakeke & \multicolumn{1}{c|}{ Taiao } & Taipūmau \\
$\begin{array}{l}\text { grounded in } \\
\text { Tākitimu }\end{array}$ & collective impact & resilient rangatahi & $\begin{array}{l}\text { whānau as critical } \\
\text { for wellbeing }\end{array}$ & $\begin{array}{l}\text { connected to our } \\
\text { environment }\end{array}$ & enduring heritage \\
\hline
\end{tabular}


community, including being supported by professionals

(Te Taitimu Trust, 2018, p. 9).

Te Taitimu Trust received Ministry of Health Te Ao Auahatanga Hauora Māori funding for Ngā Moko Ā Ngā Tūpuna at the start of 2019. This fund was established in 2009 to help reduce unmet Māori health service needs and contribute to Pae Ora (i.e., the interconnection of the wellness of: individuals / mauri ora, collectives / whānau ora, and the environment/wai ora) (Ministry of Health, 2018). The funding is designed to support innovative service delivery models that improve Māori health outcomes, particularly whānau and tamariki wellness outcomes.

The Ngā Moko Ā Ngā Tūpuna funding proposal included a navigator or Kaiwhakatere who could go into homes and the community to help ensure whānau support and participation. The Trust wanted to employ an accredited professional to engage whānau, with the Kaiwhakatere "following a kaupapa Māori pedagogical approach based on the Te Taitimu method" (Te Taitimu Trust, 2018, p. 9). The Kaiwhakatere position has been filled by Georgina Makoare who is now on a journey with rangatahi and their whānau, to encourage them out of their homes and into activities that are about service (e.g., helping load and distribute firewood to those in need), whanaungatanga and building confidence. To set the scene for a discussion of her role, we move next to look at the role of navigators more generally.

\section{Navigators}

Navigators who work with Indigenous individuals and families have been employed both inside and outside organisational settings (e.g., hospitals), often with the aim of enabling community members' access to services and helping to ensure equity of service outcomes (Cram, 2014). Navigators on the outside of services connect individuals and families with services, while those on the inside help ensure that people's pathways through a service are smoothed and successfully negotiated. Navigation, therefore, includes the removal of barriers that inhibit people's effective use of services as well as helping ensure the quality of the services being used (Ministry of Health, 2002). In the health sector, patient navigators can support patient care journeys and buffer them from a health practitioner workforce or health organisation that lacks cultural competence (Braun et al., 2012; Hill et al., 2013).

Navigators are more successful if they are not just a clip-on to existing services but have the ability to change the way existing services run (e.g., changing clinic hours, bringing community groups together inside a clinic, strengthening health practitioner competencies). In this way, a navigator might be an educator, translator, coordinator and / or peer mentor (Norris et al., 2006). For example, community navigators employed in home visiting initiatives support the families of babies and young children navigate parenthood and facilitate their access to services and supports. Gerlach (2015, p. 23), for example, describes how, in Canadian Aboriginal infant development programmes, home visitors help buffer mothers' encounters with the child welfare system by "supporting mothers who 'felt like bad parents' as a result of their interactions with the child welfare system." The building of connectedness and shared understanding by navigators helps bring a strength-based lens to engagement, whereby women and their children are seen to be full of potential (rather than a deficit-based view of them being a problem to be sorted out) (Cram et al., 2018).

Workers' strengths-based relational approach provided a critical counter narrative to women's experiences ... workers supported women's agency, resistance, and positive identity in their mothering roles, as they navigated everyday structural violence in the form of racialization, poverty and systematic dismissal and discrimination in their 
encounters with mainstream institutions. (Gerlach, 2015, pp. 24, 29)

In 2010-11 we evaluated the Kaitoko Whānau initiative (a navigation service intended to support hard-to-reach and vulnerable whānau) that predated Whānau Ora and was funded by Te Puni Kōkiri and delivered by Māori and Iwi organisations around the country. We concluded that the relationships Kaitoko Whānau built with whānau respected their mana and provided a safe space within which whānau could be Māori (Kennedy et al., 2011). More recently, the Whānau Ora (Māori family wellness) initiative has invested significantly in navigators for Māori and Pasifika whānau, providing coaching, brokerage, advocacy and other supports to whānau to enable them to implement their own plans and achieve their own goals. Gifford and Boulton (2014) write that navigators need to be the right person, namely, someone with whakapapa connections and local knowledge along with strong relationship management skills. Helen Leahy (2019, p. 1) describes the network of Whānau Ora Navigators within Te Pūtahitanga o Te Waipounamu as pivotal to whānau tranformation.

Navigation is a strength-based strategy — whānau utilise the kaupapa as a preventative measure before things spiral into a crisis situation. By connecting whānau with appropriate services, reconnecting them with their own whānau supports; and advocating on their behalf, Whānau Ora Navigators try their best to ensure whānau needs are addressed in an uplifting and holistic way. (Leahy, 2019, p. 1)

As in other Indigenous navigation services, whakawhanaungatanga-the building and strengthening of kinship relationships-has been identified as foundational to the practice of Whānau Ora navigators (Savage et al., 2017). Whakawhanaungatanga has also been recognised in the Indigenous Approach to the Living Standards Framework 2019 as central to ensuring Māori wellbeing and empowering whānau intergenerationally (Office of the Associate Minister of Housing, 2020). Navigators can therefore help unleash the potential of whānau when they have the right disposition, work in strength-based relational ways, and are prepared to understand and be responsive to the lived realities or context of the whānau they work with.

\section{Kaiwhakatere}

This description of the role of Kaiwhakatere begins with an overview of the source of Georgina's practice model; that is, her own upbringing, described here in her own words (indented below).

Even though I was not the oldest mokopuna, many of my earliest memories are of living with my grandparents and being cared for and nurtured by them. My grandmother would always cook me soft-boiled eggs on Sunday mornings and I now do this for my own mokopuna. When I was old enough to go to school, my grandparents and my mother all took me to enrol. When I was eight years old my grandfather passed away and my grandmother had to move away from the farm. I then went back to live mostly full-time with my mother and father. My relationship with my grandmother continued, with me staying with her at every opportunity right up until I married Zack. My grandmother lived to be 87 years old and was the matriarch of the whānau, whose great love for my children and mokopuna was reciprocated by them. Right up to when she passed away, she would prepare a kai for midnight on New Year's Eve and all the whānau knew that they could drop in and eat with her on that occasion.

My father was a general farmhand, so we had free rent and food from the farm. This was just as well as with three whāngai children and eight birth children, we had a big whānau, with me the eldest. I remember my mother always 
had a baby with her in the farm sheds, so she was always able to work as a cook for the shearing gang, earn money, and care for babies. A lot of responsibility for other housework and cooking for the whānau fell to me and my sister-baking on Sundays for school lunches, making the school lunches, finishing the cooking of the roast dinner that our father would get started during his lunchtime. We never went without food as there was always milk, bread and meat, topped up with what we could gather around the farm (e.g., mushrooms), grow in our own huge garden and gather from the orchards my mother would work in when shearing was quiet. Excess food was frozen or bottled. Even though we had three good meals a day, we were also mindful about what we ate as we knew we had to make food stretch.

Our woodshed was always full of wood as we would go out together on the weekends that our father was free (with our lunches made at home to take with us) to the back of the farm and cut wood. I used to love doing this as a whānau, together. It was extra special if my mother wasn't working and able to join us. I started doing this with my own children, replicating my own experiences growing up, and this is now carried forward into the Trust's work. I have more plans for bringing in other practices like relish making with the mums, when there's space to do this. Even now, we're visiting our developing papakāinga every weekend with others to do work (e.g., planting trees) with the rangatahi and the whānau connected with the Trust. I don't like missing these occasions because they're uplifting of people's-mine included-wairua.

I also spent a lot of time when I was growing up at the marae. Even though our closest marae was my father's marae, my mother spent more time there and was always there alongside my father's mother. My memories are of being 7-8 years old and working with my cousins, preparing the tables when there were tangi. Until the day she died, my mother was always at the marae-even when she worked. She tended the garden, cooked and cleaned. Zack and I and our own tamariki would often join my mother in this mahi. I therefore have good memories alongside knowledge of how valuable connections to marae are, that rangatahi and tamariki will always feel connected. This is why Te Taitimu Trust wānanga are often held at my marae. Even though it's not the flashiest marae, it's available and the rangatahi feel comfortable there. When we go there, the rangatahi learn how to set the tables, make the beds, and clean the toilets so that they know what might need to be done and how to do it. This sets them up for mahi on any marae.

The values that I grew up with also come from the time I spent staying with my uncles and aunties. I valued these times. Although I could talk to my mother about almost everything, there were some things that I talked through with my aunts. My mother gave my advice about sex and men that I still remember, and that helped me make decisions about how I wanted to be in relationships when I went to college. I've gone on to share this advice with my own sons and daughter. It has also seen me through the ups and downs in my own relationship with Zack, especially when our son took his life. I was determined that we would get through our grief together and not blame one another.

An important element of the Kaiwhakatere role has been that it should not be like more formal state-sponsored services that whānau encounter, so there are very few forms for whānau to complete and reporting is largely narrative within the case notes being kept. Although Georgina is a social worker and does not downplay this, the formal tools that she was used to using with whānau (e.g., assessments, checklists) remain in 
the "background". Her priority is firmly fixed on whanaungatanga and uplifting the mana and confidence of whānau. This approach is similar to other Māori health practitioners who describe themselves as professionally Māori; that is, they weave their professional training into their strong foundation of who they are as Māori to be both clinically and culturally competent when they engage with whānau (HollisEnglish, 2012). On top of this, their relational practice means that their "theory of change" is essentially one of whanaungatanga leading to whanaungatanga leading to whanaungatanga, as their relationships with clients are strengthened as the primary platform for any other changes to occur (Mauriora ki te Ao, 2010). Te Taitimu Trust and the Kaiwhakatere exhibit this approach within their community-driven work with rangatahi and their whānau, including the importance of creating opportunities for rangatahi to connect, build and strengthen their relationships with one another.

Alongside community-driven approaches, strategies for building youth identity, resilience and culture are becoming more widely recognised as key to Indigenous youth suicide prevention (Advisory Group on Suicide Prevention, 2005; Ngā Pou Arawhenua, Child and Youth Mortality Review Committee \& Suicide Mortality Review Committee, 2020). Sometimes young people's lives are chaotic and/or they are shy, lacking in confidence, and do not have chances and supports to fulfil their potential. They can be drawn out of themselves through the opportunities to build connections with others which, in turn, strengthen their collective resilience. In other words, whanaungatanga gives them a network of people they can call upon for friendship, support and help in times of crisis or despair (Penehira et al., 2014). As the Kaiwhakatere, Georgina can fill one of these supportive roles, a kind of professional auntie, for those who might otherwise not have or be able to call upon someone who fills this role in their lives. In turn, she is able to connect with many rangatahi and whānau through whakapapa, uncovering her auntie status within genealogy to make her role more than just a metaphor.

In her first months as Kaiwhakatere, Georgina was a key liaison between rangatahi and whānau and the Trust's fundraising activities that allow rangatahi to attend Trust wānanga and other events. This often meant she followed up the rangatahi who had attended a Trust wānanga to see what additional help and support the Trust might be able to provide to them and their whānau.

So, after every wānanga here's the list of people; here's the list of kids we can connect with, and the navigator goes out and makes the connection. (Zack at Evaluation hui, 9 April 2019).

As there are whānau costs to rangatahi involvement in wānanga (e.g., accommodation, food, entry to swimming pools), the Trust provides opportunities for them to work together with the Trust to fundraise to cover these costs. These opportunities include firewood days, where whānau come out and help chop and stack firewood (See Figure 1), and hangi fundraisers. As Zack says, the fundraising is about "not giving them a hand, but a hand-up" (Evaluation hui, August 8, 2019). While explicitly about fundraising, these activities enable whānau to engage with the Trust and with one another, often through spending the day outside working together. The firewood and other fundraising projects provide an opportunity for whānau to come "outside" and work together with those from the Trust for a common kaupapa. It is also interesting that the motivation for whānau to do this is so their tamariki and rangatahi can attend a summer camp that is all about connectivity with the environment. Rangatahi (and their whānau) collect skills (e.g., picking watercress) as well as knowledge about whakapapa and whenua that they may not have had (e.g., learning the location of their house where their nan 


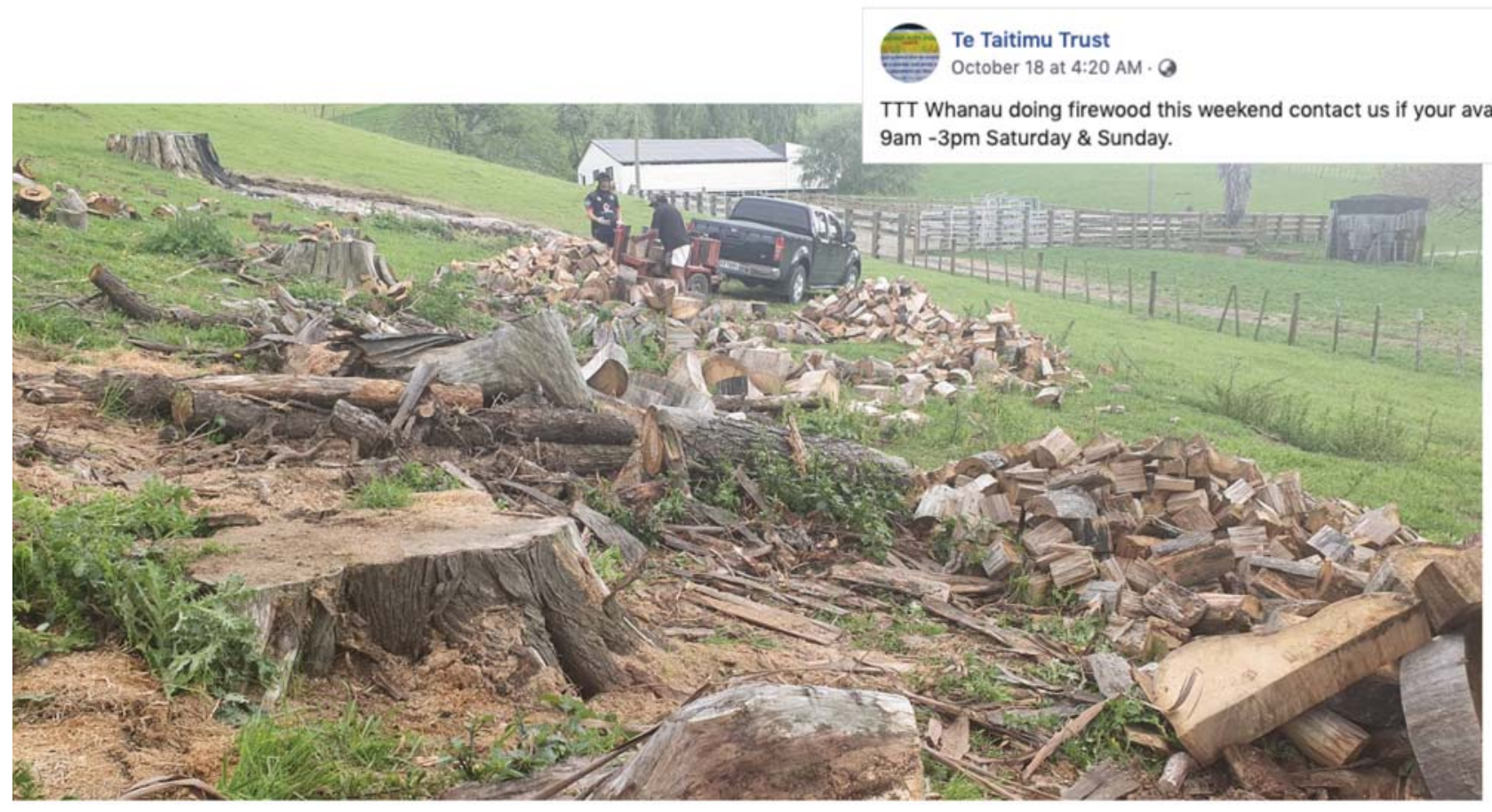

Figure 1: Te Taitimu Trust Facebook Post and Picture, October 2019.

grew up). As the Kaiwhakatere, Georgina is often able to walk alongside rangatahi and whānau to share this knowledge with them.

I love doing that stuff: the firewood, doing a hangi with the kids, showing them how to pick watercress... and how to clean it. The fact that they're eating what they picked when they have a kai and they're loving it and sometimes if there's enough, they're picking enough to take home for their whānau as well, so they feel good about that. It's basic, simple stuff but there so much learning in it that's so good for the soul, for the wairua. (Kaiwhakahere, April 16, 2020)

She was able to point out to one of the rangatahi that he was from the marae that was just across the way from where the firewood was being split, and that his grandmother had lived in a house close to the marae. She described how this rangatahi put his chest out with pride. This seemingly casual sharing of mātauranga provided a very real connection for rangatahi and whānau with their tūrangawaewae, even though they may not call it that or have visited it before.

It's the first time he's ever been on a marae, at 9 [years old], and yeah he too has whakapapa to my marae ... he just loved it, it was so good for him. (Kaiwhakatere, April 16, 2020)

Georgina's mahi with rangatahi and their whānau reflects the Trust's overall strength-based approach of supporting tamariki and rangatahi to realise their potential. She is able to connect with whānau in a way that puts them at ease. When she moves though whanaungatanga with whānau she can see them visibly relax when they realise that she's connected to them (through whakapapa and / or through experiences) and not there to judge them. They also find out that her interest is in helping them achieve their moemoeā through options such as strengthening their involvement in Trust activities. Georgina is also able to observe 
and intervene in any unsafe practices by talking with whānau about health and safety regulations when they engage with the Trust, and she supports them to connect with other support services (e.g., parenting programmes).

Her visits with whānau are not about taking a service delivery (e.g., social work) approach that focusses on solving whānau problems in order to fix things. Rather, visiting with and connecting with, whānau is more about building a trust relationship with whānau. This marks her practice as very different from the formal services (e.g., Oranga Tamariki) that whānau might usually encounter. This difference, and reports of whānau negative experiences with these formal services, provides a rationale for why a Kaiwhakatere service is needed for whānau. Overall, her approach is about enabling whānau rangatiratanga and working with them to strengthen the "good stuff". Whānau, in turn, are able to dictate their level of engagement with the Trust more generally, and Georgina can remain linked through Facebook for any whānau that may need to step back or take time out due to other events and / or pressures in their lives.

Towards the end of 2019, a small group of rangatahi was referred to the Trust by schools that felt they would benefit from going on the Trust's January 2020 summer camp. Georgina's initial approach to the whānau of these rangatahi was to talk with them and get their permission for the Trust to engage with them as a whānau and to see how she could help them get their rangatahi onto the camp. This was about going to see them, introducing herself and the Trust, whakawhanaungatanga, and getting permission from them for the Trust to be there for them. Often these rangatahi and their whānau members then engage in the Trust's fundraising activities as well as wānanga. These provide the rangatahi with opportunities to connect with whānau and whenua, which for some is a new experience. Feedback from the receptionist at one of the schools attested to the improved engagement and wellbeing of the rangatahi, and she attributed this to their experiences with the Trust.

This referral pathway was expanded in the first half of 2020, when the Trust made more formal approaches to three schools in their community to talk about the Trust's work and ask if there were any rangatahi they felt would benefit from being referred to the Trust. A referral form was developed that explicitly asks the schools if whānau are aware that a referral is being made, as well as the reasons the school is making the referral. One of the main reasons for referrals is that schools are concerned that rangatahi are not well-connected with their peer group. Schools see this as a potential barrier to the rangatahi fulfilling their potential. Once a referral is received, Georgina follows her process of visiting with a whānau, including the rangatahi, to talk more about the Trust's activities and invite the rangatahi to be involved. The ongoing nature of the Trust's activities means less pressure on rangatahi, as the activities are the Trust's usual business rather than being implemented specifically for rangatahi. Rangatahi can therefore opt in and participate in a low-key way. Georgina has already noticed that some rangatahi who are quiet and a bit hesitant to join in can change from silent passengers in the van on the way to an activity to being very chatty on the return trip. She takes this as a good sign.

\section{Taikoko practice model}

The practice model for the Kaiwhakatere role is emerging, guided by the Trust's strategic direction (see Table 1) and informed by Georgina's upbringing. Central to the Trust's work, and therefore the Kaiwhakatere role, is the creation of opportunities for rangatahi and whānau to be ordinarily Māori. Helen Moewaka Barnes (2000, p. 4) writes that "it is ironic that the concept of maori (Ryan, 1995), arising from the meaning of ordinary, is now seen as 
Table 1. Kaiwhakatere Taikoko Practice Model_Practice and Early Outcomes

\begin{tabular}{|l|l|}
\multicolumn{1}{|c|}{ TAI } & \multicolumn{1}{c|}{ Practice } \\
\hline TAITAUNGA & $\begin{array}{l}\text { Grounded in Tākitimutanga Georgina and Zack live, raise their whānau, and work in } \\
\text { their community. They are well-known and have whakapapa links with people throughout } \\
\text { Hawke's Bay. Their practice is inherently Kahungunu-Tākitimutanga, as this is the tikanga } \\
\text { and kawa that infuses their work. }\end{array}$ \\
\hline TAIOPE & $\begin{array}{l}\text { Whanaungatanga-working together Fundraising events (e.g., firewood, hangi) enable } \\
\text { whānau to strengthen relationships, with the Trust and with one another. These activities } \\
\text { encourage whānau involvement in a strengths-based way that maintains their mana. }\end{array}$ \\
\hline TAIOHI & $\begin{array}{l}\text { Resilient youth-confidence The Kaiwhakatere's mahi with rangatahi reflects the } \\
\text { Trust's overall strength-based approach of supporting rangatahi to realise their potential. } \\
\text { The Kaiwhakatere strengthens their connectedness with things Māori by sharing her } \\
\text { knowledge and skills with them. }\end{array}$ \\
\hline TAIPAKEKE & $\begin{array}{l}\text { Whānau The Kaiwhakatere visits with whānau are about the Kaiwhakatere building a trust } \\
\text { relationship with whānau so they can share their inspirations, aspirations and moemoeā. }\end{array}$ \\
\hline TAIAO & $\begin{array}{l}\text { Connection to the environment The firewood and other fundraising projects provide an } \\
\text { opportunity for whānau to come outside and work together with those from the Trust for a } \\
\text { common kaupapa. }\end{array}$ \\
\hline $\begin{array}{l}\text { Enduring heritage-mātauranga The seemingly casual sharing by the Kaiwhakatere } \\
\text { of mātauranga provides a very real connection for rangatahi and whānau with their } \\
\text { tūrangawaewae, even though they may not call it that or have visited it before. }\end{array}$ \\
\hline TAIPUMAU
\end{tabular}

the other." To regain the ordinariness of being Māori the knowledge of how to be Māori and the skills of how to do Māori are being shared by the Kaiwhakatere within the context of the Trust's activities and her own interactions with whānau and rangatahi. Learning how to set a table in a whare kai (see Figure 2), for example, means that rangatahi gain both a skill as well as an understanding of manaakitanga and mahi tahi. Similarly, going out with the Trust to cut, stack and deliver firewood is an opportunity for mahi tahi and to participate in the conversations and sharing that occur when people travel, work and eat together. The engagement of rangatahi in these activities and the ordinariness of being Māori is being positively received and having small but important impacts on rangatahi and their whānau. The challenge within a developing practice model is to capture the extraordinariness of navigating rangatahi and whānau to have ordinary Māori experiences that build knowledge, skills and collective resilience for suicide prevention.

\section{Conclusion}

Reports and commentaries about the overrepresentation of Indigenous peoples among those taking their own lives by suicide have grown increasingly clear in the past 15-25 years that the suicides of Indigenous peoples must be understood within the context of their experiences of colonisation. Similarly, the solutions proposed to eliminate these deaths by suicide, and the loss of individuals and their future generations, must address this legacy and the need for decolonisation and societal transformation if Indigenous peoples are to live good lives; that is, lives full of "purpose, hope, belonging, and meaning" that promote health and wellness (White \& Mushquash, 2016, p. 5).

This includes dismantling structural forms of racism, settling land claims, promoting community self-determination, healing from intergenerational trauma, and reducing social inequities that contribute to high 


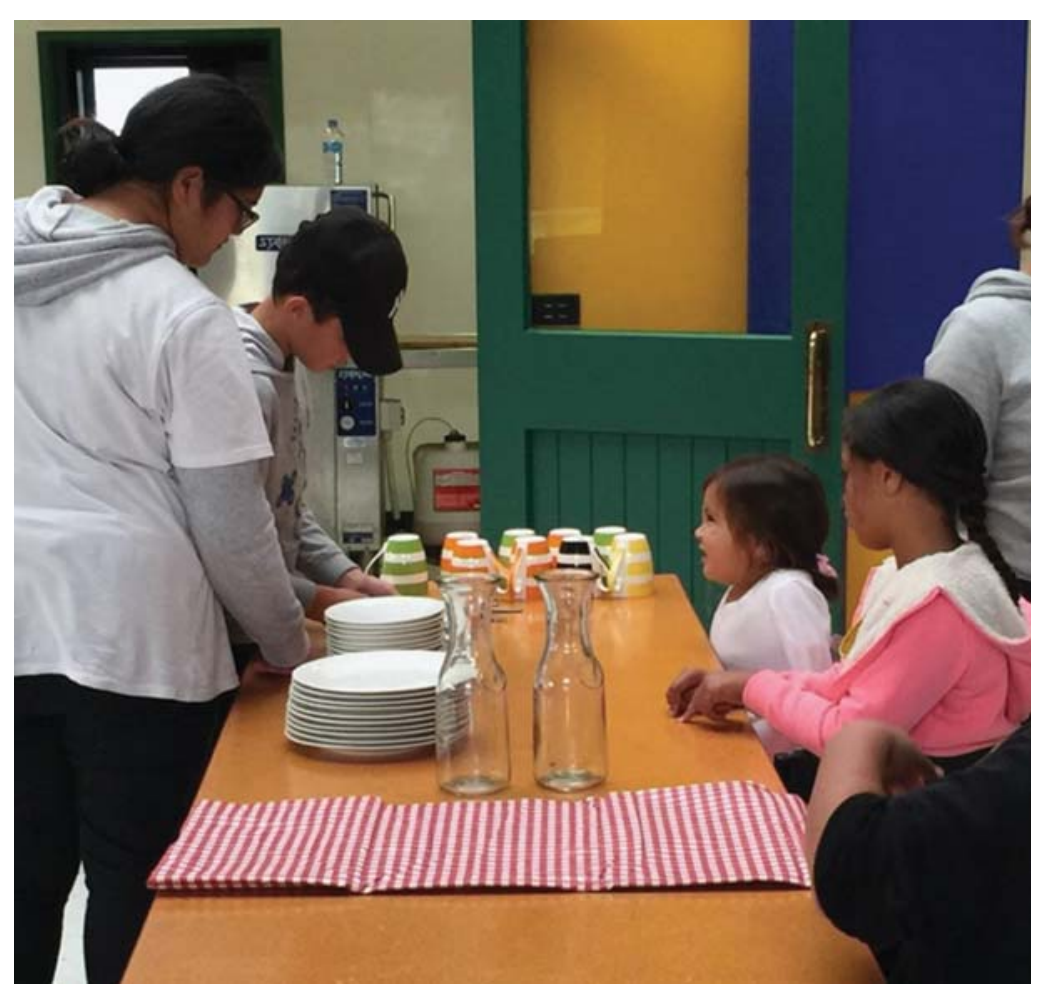

Figure 2: Marae table setting workshop (F. Cram, April 2019).

levels of hopelessness and distress among many Indigenous communities. (White \& Mushquash, 2016, p. 4)

Although being Māori used to be about being ordinary, colonisation turned this on its head through the marginalisation and exploitation of Māori by newcomers to this land. The dismantling of this change is about the reclamation of Māori as ordinary and ensuring that Māori, rangatahi included, have access to the means to both be and do Māori (Henare et al., 2011). Te Taitimu Trust creates ordinary experiences for rangatahi through its wānanga and haerenga that are (extra)ordinary by virtue of strengthening of the collective resilience of these young people. This, in turn, is key to the Trust's suicide prevention work.

The incorporation of a Kaiwhakatere role within the Trust recognises the important roles that Georgina had been fulfilling as Zack's wife and partner in the Trust. Funding for this position has enabled her to cease her work as a formal social worker and begin to explore and expand a practice model of being a professional auntie. Whānau Ora navigators and navigators working within government agency and organisational settings (e.g., hospitals) primarily navigate whānau to people, places and organisations that can support them to fulfil their aspirations for health and wellbeing. Georgina, on the other hand, navigates rangatahi and whānau to and into a whanaungatanga network through pathways of ordinary Māori experiences.

It is anticipated that the Kaiwhakatere role will continue to develop over the next 12-18 months as more feedback is gathered from rangatahi and whānau about what they value about Georgina walking alongside them and rangatahi being able to experience the Trust's activities. The goal during this time is to provide additional "proof of concept" that whānau benefit from an authentic trust relationship with a Kaiwhakatere who is committed to seeing young people safe and fulfilling their potential.

Acknowledgement: Many thanks to the staff of Te Taitimu Trust and the reviewers for their encouragement and feedback.

Accepted 30 January 2021

Published 25 April 2021

\section{Glossary}

Source. Māori-English English-Māori Dictionary online (www.maoridictionary.co.nz)

atua ancestor with continuing influence, god

haerenga journey, trip

Kaiwhakatere navigator, professional auntie 


\begin{tabular}{|c|c|c|c|}
\hline \multirow[t]{2}{*}{ karakia } & \multirow[t]{2}{*}{$\begin{array}{l}\text { prayer, } \\
\text { incantation }\end{array}$} & Tai Mātātū & turning the tide \\
\hline & & Taikoko & rising spring \\
\hline kaupapa & $\begin{array}{l}\text { ground rules, } \\
\text { agenda }\end{array}$ & & tide \\
\hline & & Tākitimutanga & ways sourced \\
\hline kawa & $\begin{array}{l}\text { etiquette, } \\
\text { protocol }\end{array}$ & & $\begin{array}{l}\text { from those on } \\
\text { the Tākitimu } \\
\text { migration }\end{array}$ \\
\hline mahi & work & & canoe \\
\hline \multirow[t]{2}{*}{ mahi tahi } & to work & tamariki & children \\
\hline & $\begin{array}{l}\text { together, } \\
\text { cooperate, } \\
\text { collaborate }\end{array}$ & Tangaroa & $\begin{array}{l}\text { atua of the sea } \\
\text { and fish }\end{array}$ \\
\hline \multirow[t]{3}{*}{ marae } & $\begin{array}{l}\text { courtyard, } \\
\text { forecourt of }\end{array}$ & tangi, tangihanga & $\begin{array}{l}\text { funeral, rites for } \\
\text { the dead }\end{array}$ \\
\hline & $\begin{array}{l}\text { building. Often } \\
\text { also used to } \\
\text { include the }\end{array}$ & tīpuna, tūpuna & ancestors \\
\hline & $\begin{array}{l}\text { complex of } \\
\text { buildings } \\
\text { around the marae }\end{array}$ & tūrangawaewae & $\begin{array}{l}\text { place where } \\
\text { one has the } \\
\text { right to stand - } \\
\text { place where }\end{array}$ \\
\hline mātauranga & $\begin{array}{l}\text { knowledge, } \\
\text { wisdom, } \\
\text { understanding }\end{array}$ & & $\begin{array}{l}\text { one has rights } \\
\text { of residence } \\
\text { and belonging } \\
\text { through kinship }\end{array}$ \\
\hline moana & sea, lake, ocean & & and whakapapa \\
\hline \multirow[t]{2}{*}{ Whānau Ora } & Māori family & wairua & spirit \\
\hline & & wānanga & deliberations, \\
\hline moemoeā & dream, vision & & $\begin{array}{l}\text { forum, } \\
\text { educational }\end{array}$ \\
\hline \multirow[t]{2}{*}{ moko, mokopuna } & grandchild, & & seminar \\
\hline & $\begin{array}{l}\text { grandchildren, } \\
\text { great- } \\
\text { grandchildren }\end{array}$ & whakapapa & $\begin{array}{l}\text { genealogy, } \\
\text { lineage, descent }\end{array}$ \\
\hline papakāinga & $\begin{array}{l}\text { original home, } \\
\text { home base, village }\end{array}$ & whakawhanaungatanga & $\begin{array}{l}\text { the process of } \\
\text { establishing } \\
\text { relationships }\end{array}$ \\
\hline rangatiratanga & $\begin{array}{l}\text { self- } \\
\text { determination, } \\
\text { sovereignty }\end{array}$ & whānau & $\begin{array}{l}\text { family collective, } \\
\text { extended family } \\
\text { group }\end{array}$ \\
\hline tai & tide, sea & whenua & land \\
\hline
\end{tabular}




\section{References}

100 Māori Leaders. (2019). Zack Makoare Ngāti Kahungunu. https://100maorileaders.com/zack-makoare

Advisory Group on Suicide Prevention. (2005). Acting on what we know: Preventing youth suicide in First Nations. Government of Canada.

Braun, K. L., Kagawa-Singer, M., Holden, A. E., Burhanssitpanov, L., Ran, J. H., Seals, B. F., CorbieSmith, G., Tsark, J., Harjo, L. Foo, M. A., \& Ramirez, A. G. (2012). Cancer patient navigator tasks across the cancer care continuum. Journal of Health Care for the Poor and Underserved, 23(1), 398-413.

Cram, F. (2014). Improving Māori access to health care: Research report for the Ministry of Health. Katoa Ltd.

Cram, F., Vette, M., Wilson, M., Vaithianathan, R., Maloney, T., \& Baird, S. (2018). He awa whiria-braided rivers: Understanding the outcomes from Family Start for Māori. Evaluation Matters-He Take Tō Te Aromatawai, 4, 165-206.

Durie, M. (2018). Te Taiao: Māori mental health in twentyfirst-century environments. In T. Kingi, M. Durie, $\mathrm{H}$. Elder, R. Tapsell, M. Lawrence, \& S. Bennett (Eds.), Maea te toi ora: Māori health transformations. Huia.

Gerlach, A. (2015). Relational pathways in early intervention. Research summary report. Aboriginal Infant Development Program of British Columbia.

Gifford, H., \& Boulton, A. (2014). Whānau ora: Reflecting on results from action research. International indigenous development research conference proceedings (pp. 9-15). Auckland: Ngā Pae o te Māramatanga. www.indigenousdevelopment2014.ac.nz http://www. maramatanga.ac.nz/sites/default/files/ IIDRC

Henare, M., Puckey, A., Nicholson, A., Dale, M. C., \& Vaithianathan, R. (2011). He ara hou: The pathway forward. Getting it right for Aotearoa New Zealand's Māori and Pasifika children. Every Child Counts.

Hill, S., Sarfati, D., Robson, B., \& Blakely, T. (2013). Indigenous inequalities in cancer: What role for health care? Australia New Zealand Journal of Surgery, 83, 36-41.

Hollis-English, A. N. R. (2012). Māori social workers: Experiences within social service organisations. [Unpublished doctoral dissertation, University of Otago].

Kennedy, V., Paipa, K., \& Cram, F. (2011). Evaluation of the Kaitoko Whānau initiative. A report prepared for Te Puni Kōkiri. Katoa.

Leahy, H. (2019, July 23). Whānau Ora navigators key in early intervention. Te Pūtahitanga o Te Waipounamu. http://www.teputahitanga.org/media-releases/navigatorskey-to-early-intervention

Macfarlane, T. (2019). Report on Te Taipari 2040 Agenda wānanga. Te Taitimu Trust.

Mauriora ki te Ao. (2010). Whānau ora integrated services delivery. Ministry of Health.

Ministry of Health. (2002). Reducing inequalities in health. Ministry of Health.

Ministry of Health. (2018). Te Ao Auahatanga Hauora Māori Māori Health Innovation Fund: Fund Guidelines 2018. Te Kākano/Seeding Innovation for new innovative approaches to service delivery. Ministry of Health.

Moewaka Barnes, H. (2000). Kaupapa maori: Explaining the ordinary. Whariki Research Group, Alcohol \& Public Health Research Unit, University of Auckland. http:// www.rangahau.co.nz/assets/BarnesH/explaining_the_ ordinary.pdf.

New Zealand Police. (2019, February 25). Hikoi of resilience down the Whanganui Awa with our partners helping "Turn the Tide". New Zealand Police. https://www.police. govt.nz/news/ten-one-magazine/hikoi-resilience-downwhanganui-awa-our-partners-helping-"turn-tide"

Ngā Pou Arawhenua, Child and Youth Mortality Review Committee \& Suicide Mortality Review Committee. (2020). Te Mauri-The life force. Rangatahi suicide report | Te pūrongo mō te mate whakamomori o te rangatahi. Health Quality and Safety Commission.

Norris, S. L., Chowdhury, F. M., Van Let, K., Horsley, T., Brownstein, J. N., Zhang, X., Jack, L. Jr, \& Satterfield, D. W. (2006). Effectiveness of community health workers in the care of persons with diabetes. Diabetic Medicine, 23(5), 533-556.

Office of the Associate Minister of Housing. (2020). Te Maihi o te Whare Māori - the Māori and Iwi Housing Innovation (MAIHI) Framework for Action. Cabinet Paper, to the Chair, Cabinet Social Wellbeing Committee. Housing and Urban Development. https://www.hud.govt.nz/ assets/News-and-Resources/Proactive-Releases/ Cabinet-Paper-Te-Maihi-o-te-Whare-Maori-the-Maoriand-Iwi-Housing-Innovation-MAIHI-Framework-forAction.pdf

Penehira, M., Green, A., Smith, L. T., \& Aspin, C. (2014). Måori and Indigenous views on R \& R: Resistance and reliance. MAI Journal, 3(2), 96-110.

Savage, C., Dallas-Katoa, W., Leonard, J., Goldsmith, L., \& Fraser, W. (2017). Whānau ora navigation: Initial research for Te Putahitanga o Te Waipounamu. Ihi Research.

Te Puni Kōkiri (2016). The Whānau ora outcomes framework: Empowering whānau into the future. Te Puni Kōkiri. www.tpk.govt.nz/docs/tpk-wo-outcomesframeworkaug2016.pdf.

Te Puni Kōkiri. (2018). Hawkes Bay rangatahi gather for rangatahi suicide prevention. Retrieved July 2019, from Te Puni Kōkiri: https://www.tpk.govt.nz/en/mo-te-punikokiri/our-stories-and-media/hawkes-bay-rangatahigather-for-rangatahi-suicide-

Te Puni Kōkiri. (2019). Rangatahi suicide prevention. Retrieved July 2019, from Te Puni Kōkiri: https://www. tpk.govt.nz/en/whakamahia/rangatahi-suicide-preventio

Te Taitimu Trust. (2018). Part 2: Proposal response form. Te Ao Auahatanga Hauora Māori: Māori health innovation fund 2018-2022. Te kākano/seeding innovation category. Te Taitimu Trust.

Waka Hourua. (2017). Te Taitimu Trust (Hawkes Bay). Waka Hourua. http://wakahourua.co.nz/oldsite/te-taitimu-trusthawkes-bay

Water Safety New Zealand. (2018, January 22). Partnership to improve water safety skills of Maori youth in Hawkes Bay. Water Safety New Zealand. https://watersafety. org.nz/partnership\%20to\%20improve\%20water\%20 safety $\% 20$ skills $\% 20$ of $\% 20$ maori\%20youth $\% 20$ in $\% 20$ hawkes\%20bay

White, J., \& Mushquash, C. (2016). We belong: Life promotion to address indigenous suicide. Discussion paper. Thunderbird Partnership Foundation. 